\title{
A Survey of Foreign Students' Satisfaction with Studying in Xi'an*
}

\author{
Lijuan Gao \\ School of Liberal Arts \\ Xi'an FanYi University \\ Xi'an, China 710105
}

\begin{abstract}
The study on the satisfaction of foreign students belongs to the category of cross-cultural adaptation research, and the questionnaire survey will be carried out from two aspects of social distance and psychological distance. Through the survey of students' life satisfaction in 7 schools in Xi'an, the degree of their cultural adaptation will be measured, and the cross-cultural adaptation model for the international students in Xi'an students will be put forward according to the results of the survey.
\end{abstract}

Keywords-foreign students; overseas students from Xi'an; life satisfaction

\section{INTRODUCTION}

Since the successful hosting of the Olympic Games in Beijing in 2008, China has ceased to be the image of backwardness in the hearts of the people of the world. Accordingly, Chinese has also become a hot language in the world. Studying in China has become a popular choice for a new generation of foreign students. Therefore, it is imminent to improve the education management of overseas students in China. Doing a good job about international students in China is not only of great significance to promote the reform and development of education, but also has far-reaching political and economic significance.

With the rapid economic, social and cultural development along the "Silk Road", the exchanges between Xi'an and the world have increased. In terms of cultural exchanges, due to its special geographical location and profound cultural heritage, more and more students have come to Xi'an to study and live. $\mathrm{Xi}$ 'an has a long history, but at the same time it is full of modernity. It itself is already a popular tourist destination for Chinese and foreign tourists. What's more, Xi'an has a higher level of higher education and gathers nearly a hundred colleges and universities, which will undoubtedly create more choice opportunities for overseas students in China. Moreover, Xi'an is close to Middle East countries in terms of geographical location, so, their cultural exchanges, economic and trade exchanges are quite frequent. If coming to study in China, Xi'an should be the first choice for students from these countries.

*This paper is supported by education department projects in Shaanxi The Application Study on Cultural Accommodation in Chinese International Education (Project Number:17JK0975).
The continuous increase in the number of international students coming to China has undoubtedly raised new issues and challenges for the education management of overseas students in various universities. China has vast territory and abundant resources, different geographical location, and great differences in humanities and local dialects. Even if the Chinese students from the Southern China region still need to adapt themselves to the local environment and culture in North China, so, the international students in different regions cannot generalize the model of their life and study in China. Xi'an is located in northwestern China, and it is representative, targeted, and practical taking it as a research object in the region. This paper will use several colleges and universities in Xi'an as individual cases to design a questionnaire for "survey of the satisfaction of foreign students living in Xi' an," according to the specific conditions of these international students, and the data collection and statistical analysis will be followed to help the various universities in the region to understand and provide theory basis for international students in China to adapt to the local life so as to achieve comprehensive improvement of overseas students to quickly adapt to the study and life in Xi'an.

\section{LITERATURE REVIEW SECTION}

This study intends to collect a large amount of literature to master comprehensive relevant literature, and use adaptability research theories of foreign students at home and abroad as well as apply the theoretical basis for adaptability to Xi'an characteristics to summarize the literature overview of this topic by comprehending, collating and merging, .

\section{A. Overview of Foreign Research}

The survey of foreign students' satisfaction with living in Xi'an belongs to a category of cross-cultural adaptation research. The study of cross-cultural adaptation began in the early 20th century in the United States. The theory was first proposed by three Americans, Robert Laidfeld, Ralph Linton, and Melville Heskowitz. They believed that cross-cultural adaptation consists of individuals, and there are changes of two cultural patterns that result from the continuous exposure of two groups of different cultures.

At the beginning of the 20th century, the United States, the United Kingdom, Australia, Canada and other countries have carried out one after another in this field. The study of cross- 
cultural adaptation in the 1970s mainly focused on the negative consequences of cross-cultural exposure. And the study emphasized theoretical explanations. Moreover, they lacked experimental research, but just emphasized theoretical explanation. After the 1980s, the research has begun to shift to focus on cross-cultural communication at the individual level and the discussion of various factors from the cultural changes and cultural integration at the group level. In addition to linguistics, anthropology, sociology, social psychology, and communication have all been involved in the study of crosscultural adaptation, thus enriching the study of cross-cultural groups.

Foreign scholars have proposed different classifications for cross-cultural adaptation. Most researchers agree that the classification of cross-cultural adaptation is divided into two dimensions: psychological adaptation and sociocultural adaptation. Psychological adaptation is based on emotional reactions, referring to mental health and life satisfaction in cross-cultural contact. Social adaptation refers to the ability to adapt to the local social and cultural environment and whether it can effectively contact and communicate with people with local culture. Black divides cross-cultural social adaptation into three dimensions: general adaptation, work adaptation, and interact adaptation. General adaptation refers to the dimensions of adaptation of food, housing, living expenses, and health and medical life in an exotic daily living culture. Workability adaptation refers to the adaptation of new work tasks, roles, responsibilities, and the environment. Communication adaptation refers to the sense of comfort and proficiency felt in social interaction with host countries.

From the perspective of cross-cultural adaptation, there are several recognized theories and they are respectively the UCurve model of culturally anthropologist Kalvero Oberg, also known as "Culture Impact Theory", and the Cultural Change Curve of Guertz, Louis's surprise and Rational Search Model theory, and the Adaptation Model put forward by Korean psychologist Kim Yong (Yong Yun Kim).At the same time, foreign scholars are also involved in the study of the impact of cross-cultural adaptation. They proposed that cross-cultural adaptation should pay attention to cultural maintenance and contact and participation.

In terms of cross-cultural adaptation research, "the Influence and Adaptation of Foreign Students from a Comparative Perspective," written by Alterbach (1991), a comparative education research expert is a representative masterpiece in comparative education field on the issue of cross-cultural adaptation of international students. The research abroad emphasizes the construction of the theory, which also provides a theoretical basis for the investigation and study of life satisfaction of international students in Xi'an.

\section{B. The Review of Domestic Research}

The research on the adaptability of foreign students in China is divided into two aspects. One is the research on the adaptability of Chinese students studying abroad; the other is the research on the adaptability of foreign students in China. There are not many relevant studies on foreign students in China. With the titles of "Students coming to China" and "Students studying in China", there are about 150 related papers in the China Academic Journal Network. The vast majority of them are journal articles. There are only a limited number of doctoral thesis articles, and most of them are constructed by citing the theory of foreign research. However, it is worth noting that most of the domestic studies have focused on the characteristics of China's local students to conduct research, even for certain areas of relevant research. Compared with foreign studies, it is more focused and more practical.

The article on the adaptability of international students for a certain region in China is also a new highlight and focus. Chen Hui (2003) also analyzed the cross-cultural adaptation of international students in Beijing and its influencing factors from the perspective of psychology. The master thesis of Bai Lan, a student of Grade 2011 of Shaanxi Normal University, "On the Intercultural Adaptation of the American International Students Studying in the Xi'an City, Xi'an," carried out study of the local students from the perspective of the Xi'an American students, which provided a good example for this study.

\section{RESEARCH METHODS AND PROCESSES}

Based on the premise of "Survey of Xi'an International Students' Life Satisfaction," the researchers set up a questionnaire survey and adopted the principle of maximum sampling, selecting 40 international students from 2 universities in Xi'an for communication. The author consulted the relevant literature and data, combined the two to determine the questionnaire survey. The scope of the questionnaire is mainly about the "cultural adaptation model" proposed by the American scholar John H. Schumann, starting from the dimensions of eight factors of social distance and the four factors of psychological distance, which not only affect the life satisfaction of international students, but also are closely related to the second language acquisition.

TABle I. The Relationship between Social Distance and the SeCond Language ACQuisition

\begin{tabular}{|l|l|l|l|l|l|l|l|l|}
\hline \multicolumn{1}{|c|}{$\begin{array}{c}\text { Social } \\
\text { Distance }\end{array}$} & $\begin{array}{c}\text { Social Leading } \\
\text { Model }\end{array}$ & $\begin{array}{c}\text { Integration } \\
\text { Strategy }\end{array}$ & $\begin{array}{c}\text { Degree of } \\
\text { Closure }\end{array}$ & $\begin{array}{c}\text { Concentration } \\
\text { Degree }\end{array}$ & $\begin{array}{c}\text { Group } \\
\text { Size }\end{array}$ & $\begin{array}{l}\text { Cultural } \\
\text { Similarity }\end{array}$ & $\begin{array}{l}\text { Attitude } \\
\text { to Live }\end{array}$ \\
\hline Helps to learn & Equal status & $\begin{array}{l}\text { Assimilation } \\
\text { and } \\
\text { adaptation }\end{array}$ & Low level & Low level & Small & Tall & Positive & Long \\
\hline $\begin{array}{l}\text { Fail to help } \\
\text { learn }\end{array}$ & $\begin{array}{l}\text { Dominance and } \\
\text { subordination }\end{array}$ & Reservation & High level & High level & Big & Low & Negative & Short \\
\hline
\end{tabular}


TABLE II. RELATIONSHIP BETWEen Psychological Distance AND SECOND LANGUAGE ACQUiSition

\begin{tabular}{|c|c|c|c|c|}
\hline Psychological Distance & Language Shock & Cultural Shock & Learning Motivation & $\begin{array}{c}\text { Language Boundary } \\
\text { Permeability }\end{array}$ \\
\hline Helps to learn & Low level & Low level & Convergence motive & Strong permeability \\
\hline Fail to help learn & High level & High level & Instrumental motivation & Poor permeability \\
\hline
\end{tabular}

Questionnaires were issued and collected in a face-to-face manner and are voluntarily selected to complete the questionnaire. After the questionnaires were withdrawn, the investigators used Excel to conduct preliminary descriptive statistical analysis of the collected data, and calculated the average and percentage of satisfaction of each question, thereby visually observing the situation of life satisfaction for international students in Xi'an. Then, SPSS2.0 was used to describe, analyze, infer and summarize the data, and investigated from different dimensions.

\section{RESEARCH OBJECTS AND STATISTICAL RESULTS}

Students from Northwestern University, Shaanxi Normal University, Xi'an Petroleum University, Xi'an International Studies University, the Xi'an FanYi University, Xi'an Bo-Ai International School and the Xi'an International House are the subjects of the study. Because Xi' an is the starting point of the Silk Road, there are 210 international students surveyed and 210 valid questionnaires. Among them, $73.2 \%$ of the international students are from Central Asia, which not only indicates the structural deviation of the questionnaire data collection, but also reflects the distribution of nationalities deviation of Xi'an international students. Of the students participating in the survey, there are 56 middle school students (26.7\%), 93 undergraduates $(44.28 \%)$ and 61 graduate students $(29.05 \%)$. What's more, $195(92.86 \%)$ of them have study experience in China in earlier days.

\section{PROBlEMS IN CROSS-CULTURAL ADAPTATION FOR INTERNATIONAL STUDENTS IN XI'AN}

The problems in cross-cultural adaptation of Xi'an students are mainly social distance and psychological distance. For example, it is the environment, facilities, and queuing of public toilets that are difficult to adapt for Xi'an international students; there is also interference from Xi'an's table culture, dining table tools, and some diets. Therefore, the problem of students' lives will lead to their psychological problems, which further contributes to their academic work.

\section{A. Language Shock}

Although most of the Xi'an students have studied Chinese before they came to $\mathrm{Xi}^{\prime}$ an, they are not confident enough when applying and will have a certain sense of fear. Therefore, she may be ashamed to open her mouth because she is afraid to say something wrong, or worry that she will fail to express what she want to say so that language shock maybe happens. Severe persons may be refuse to cooperate with the target speaker to complete an activity as much as possible.

\section{B. Cultural Shock}

When entering an unfamiliar cultural environment, many people will be at a loss. The following things may happen: they may be unable to do what they could in previous days because they could not find a place; the usual method of solving problems will no longer work; and communication with people will encounter obstacles. All these may lead that the heart will be empty and helpless. For example, some international students will rent out their houses outside the school. When their home equipment or accessories are damaged, they feel particularly helpless; after buying clothes, because the number is not appropriate, they do not know how to quickly change to the number they want. Therefore, some international students need to integrate into a new culture for a long period of time before they can even learn.

\section{Difficulties in Social and Cultural Adaptation}

When dealing with administrative agencies, there is no public appointment procedure. So, when they do things, they will waste a lot of time and energy in waiting. In terms of public services, international students have higher requirements for service personnel in the window industry, and they feel that Xi'an public service personnel have a weak sense of service, and the service quality is not as good as their own.

\section{STRATEGIES FOR IMPROVING CROSS-CULTURAL ADAPTATION OF FOREIGN STUDENTS IN XI'AN}

For the cross-cultural adaptation problem of international students coming to $\mathrm{Xi}^{\text {' }}$ an, some departments in $\mathrm{Xi}^{\text {' an }}$ should actively assist in the construction of an international metropolis and provide the international students with care and concern for their lives.

\section{A. Improve Service Quality, Public Facilities and Multi Lingual Slogans of Xi'an Public Platforms.}

$\mathrm{Xi}^{\prime}$ an is an international metropolis. In recent years, many foreign guests and international students have been attracted by various reasons. However, foreign students have a lot of confusion after living in Xi'an. For example, the instruction of the street is only Chinese, and it is suggested that the language on the brand should be as multilingual as possible. Bus drivers can only speak Chinese. It will be better if they can speak simple English or Korean. It is recommended that the staff of the public platform be able to diversify their language.

\section{B. Integrate School Resources and Make Full Use of Resources}

The schools we conduct research are both have Chinese students and international students. They all have a strong faculty and high-quality learning resources. If reorganize these resources and maximize the use of resources within our school, it is necessary to establish a professional training system firstly and improve the English teaching system based on the data analysis of the academic situation and education and teaching. According to the training plan, colleges and universities can use the first-level discipline as the basis to come up with a 
discipline that is suitable for internationalized recruitment and training. In $50 \%-70 \%$ of the courses, bilingual education should be provided, including public basic courses, professional basic courses, and professional courses, building up a complete international student training program. The classroom teaching model also needs to be improved. There is no unique opinion about changing the traditional Chinese teaching model and giving a crammed class.

\section{Organize Diversified Activities to Promote the Integration of International Students into Chinese Culture}

At present, most international students eat and live in schools, and their exchange groups are also international students. The frequency of activities is relatively low. It is suggested that schools should provide foreign students with a platform for cooperation and exchange with local people and provide a variety of channels for understanding Chinese culture. For example, the school can provide the Chinese and Western student unions. In the meantime, it's feasible for the government to provide chances to encourage international students to participate in charity volunteer activities so that they can integrate into Xi'an life.

\section{Strengthen the Construction of Xi'an Chinese Language Training Bases and Open Psychological Consultation Institutions for International Students}

For example, the government provides financial incentives or the policy tends to support the construction of training grounds for learning Chinese as a foreign language. Schools should set up specialized psychological counseling institutions for overseas students to provide cross-cultural psychological counseling and provide consultation to help overseas students adapt smoothly to study abroad. Similarly, at the University of Toronto, there is a cross-cultural consulting position, where the psychological counseling professionals serve. Therefore, colleges and universities receiving international students in Xi'an should build a cross-cultural psychological counseling mechanism based on the International Student Office as soon as possible.

\section{E. Pay Attention to the Employment of Overseas Students and Establish an Employment Service System for Overseas Students}

Wang Yong (2014) pointed out in the survey on "Satisfaction of International Student Education Management Work in China: Composition, Contribution, and Strategy": the school's employment guidance service has not been opened to foreign students on a large scale. Maybe due to the small scale, the service for international students has not yet formed a system and the quality of service will be affected as a result. Therefore, it is suggested that the school pays attention to the employment of overseas students and establishes a guidance course on employment for overseas students, including how to interview and how to understand the needs of the Chinese talent market; establish an employment service system for overseas students that shall be led by the Office of International Students and the Employment Office should be responsible for completing the job specifically.

\section{CONCLUSION}

Through the survey for the life satisfaction of the international students in Xi'an, the following conclusions have been drawn: students studying in Xi' an should communicate with local people as much as possible to reduce language shock, and participate in local activities as much as possible to reduce cultural shocks. It's better for them to understand Chinese culture from different sources, and like Xi' an, an international metropolis, as soon as possible. Xi'an Municipal Government attaches great importance to the construction of public platforms and raises awareness of international services to attract more international students.

\section{REFERENCES}

[1] Junhong Yang. Study on Intercultural Adaptation of Foreign Students in China[D].East China Normal University. 2005 Doctoral Dissertation. 杨 军红. 来华留学生跨文化适应问题研究[D].华东师范大学 2005 级博 士论文。

[2] Mei Wan. A Summary of Studies on Cross-cultural Adaptation of Foreign Students in China[J].Modern Education Science • University ResearchNo.6 of 2008. 万梅. 关于来华留学生跨文化适应问题研究的 综述 $[\mathrm{J}]$.现代教育科学・高校研究 2008 年第 6 期。

[3] Lijuan Wang. The Status Summary of Cross-cultural adaptation research [J]. Shandong Social Science No. 4 of 2011. 王丽娟. 跨文化适 应研究现状综述[J].山东社会科学 2011 年第 4 期。

[4] Longyun Lei Yiqun Gan. Cross-cultural Adaptation Survey o International Students in China[J].Chinese Mental Health Journal • Investigation and Research Vol.18 No. 10 2004 雷龙云 甘怡群. 来华留学生的跨文化适应状况调查[J].中国心 理卫生杂志・调查研究 2004 年第 18 卷第 10 期。

[5] Jianqin Wang. Second Language Acquisition Research[M].The Commercial Press, 2011 年 4 月. 主建勤.第二语言习得研究[M]. 商务 印数馆, 2011 年 4 月 